\title{
Flat foveal contour simulating macular hole
}

\author{
Vinod Kumar, Prasad Nandlal Gupta
}

Dr Rajendra Prasad Centre for Ophthalmic Sciences, All India Institute of Medical Sciences, New Delhi, Delhi, India

\section{Correspondence to Dr Vinod Kumar, drvinod_agg@yahoo.com}

Accepted 10 November 2017 CrossMark

To cite: Kumar V, Gupta PN. BMJ Case Rep Published Online First: [please include Day Month Year]. doi:10.1136/bcr-2017222868

\section{DESCRIPTION}

A 40-year-old healthy female was referred for macular hole in his both eyes detected during routine examination. Visual acuity was $20 / 20$ OU unaided. Ocular examination of OD was unremarkable except for the presence of round red lesion at fovea (figure $1 \mathrm{~A}$, arrow) that was more prominent on green reflectance imaging (figure 1B, arrow). Spectral-domain optical coherence tomography showed a flattened foveal contour (figure 1C, arrows), which explained the appearance of macular hole. Similar findings were seen in OS. There were no ocular or systemic features suggestive of albinism.

The foveal contour and anatomy may vary in different individuals. In a study of normal foveal

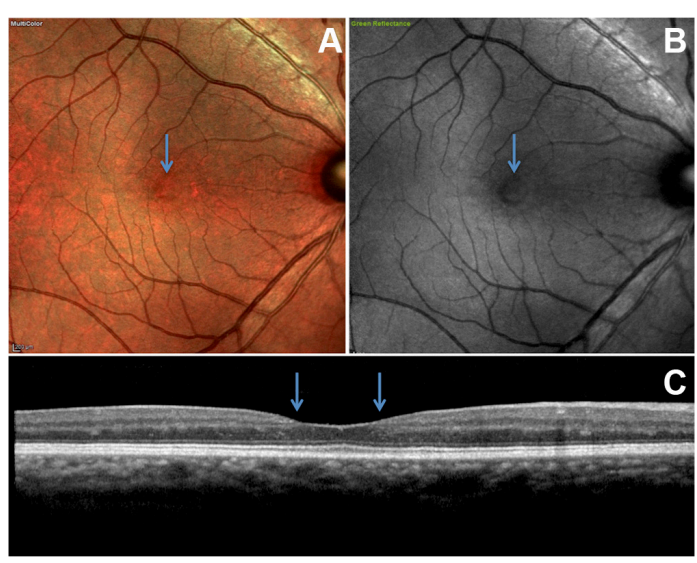

Figure 1 Multicolour scanning laser image of right eye showing small red lesion (arrow) simulating macular hole (A) that is better seen on red free image (B). Apparent macular hole corresponds to flat foveal contour on optical coherence tomography (C).

\section{Learning points}

- Foveal contour may vary in normal population.

- Flat foveal contour may simulate a macular hole.

- Optical coherence tomography is a useful tool to differentiate macular hole from flat foveal contour.

contour and thickness by Tick et al, the foveal thickness was least in the eyes where inner nuclear layer was not continuous over the fovea. ${ }^{1}$ These eyes had flat foveal pit and was seen in $7.3 \%$ of the cases. The presence of flat foveal pit in conjunction with thinner retina at fovea allows better appreciation of choroidal red reflex in a small circular area that can simulate a lamellar or full thickness macular hole. These images emphasises that flat foveal contour can simulate macular hole and that optical coherence tomography is useful in differentiating flat foveal contour from macular hole.

Contributors VK, PNG: concepts, design, definition of intellectual content, clinical studies, data analysis and manuscript review. VK: literature search, manuscript preparation and manuscript editing. PNG: data acquisition. Statistical analysis NA. not applicable

Competing interests None declared.

\section{Patient consent Obtained.}

Provenance and peer review Not commissioned; externally peer reviewed.

(C) BMJ Publishing Group Ltd (unless otherwise stated in the text of the article) 2017. All rights reserved. No commercial use is permitted unless otherwise expressly granted.

\section{REFERENCE}

1 Tick S, Rossant F, Ghorbel I, et al. Foveal shape and structure in a normal population. Invest Ophthalmol Vis Sci 2011;52:5105-10.
Copyright 2017 BMJ Publishing Group. All rights reserved. For permission to reuse any of this content visit

http://group.bmj.com/group/rights-licensing/permissions.

BMJ Case Report Fellows may re-use this article for personal use and teaching without any further permission.

Become a Fellow of BMJ Case Reports today and you can:

- Submit as many cases as you like

- Enjoy fast sympathetic peer review and rapid publication of accepted articles

- Access all the published articles

- Re-use any of the published material for personal use and teaching without further permission

For information on Institutional Fellowships contact consortiasales@bmjgroup.com

Visit casereports.bmj.com for more articles like this and to become a Fellow 